\title{
Penentu Pergerakan Hasil Bon Kerajaan di Malaysia: Analisis Model Auto Regresif Lat Tertabur (ARDL)
}

(The Determinants of Government Bond Yield Movement in Malaysia: An Analysis of Autoregressive Distributed Lag Model)

\author{
MAZWINDA MAWARDI, ZULKEFLY ABDUL KARIM* \& BAKRI ABDUL KARIM
}

\begin{abstract}
ABSTRAK
Pergerakan hasil bon kerajaan memainkan peranan yang penting kepada tadbir urus ekonomi sesebuah negara khususnya kepada pihak kerajaan, pelabur dan pengurus dana. Kadar hasil bon kerajaan yang relatif tinggi akan meningkatkan kos pembayaran kadar bunga oleh pihak kerajaan, dan jika berpanjangan situasi ini akan menjejaskan kedudukan kewangan kerajaan pada masa hadapan. Justeru, kajian ini bertujuan untuk menganalisis faktor-faktor yang mempengaruhi pergerakan kadar hasil bon kerajaan berdasarkan kepada tiga bentuk struktur tempoh kadar bunga iaitu bon jangka pendek, jangka sederhana dan jangka panjang. Model penentu kadar hasil bon telah dianalisis dengan menggunakan kaedah auto regresif lat tertabur (ARDL). Hasil kajian mendapati berlakunya kointegrasi atau hubungan jangka panjang antara pemboleh ubah defisit fiskal, hutang kerajaan, kadar pertukaran asing, dan kadar pertumbuhan ekonomi ke atas ketiga-tiga struktur tempoh hasil bon kerajaan tersebut. Selain itu, dalam jangka panjang, defisit fiskal, hutang kerajaan dan kadar pertukaran mempunyai pengaruh yang signifikan ke atas hasil bon kerajaan. Penemuan kajian ini menunjukkan penggubal dasar fiskal perlu lebih berhati-hati dalam mentadbir urus belanjawan defisit dan hutang negara, di samping peranan Bank Negara Malaysia dalam mengawal kestabilan kadar pertukaran asing bagi memastikan kestabilan kadar bunga bon-bon kerajaan untuk kepentingan negara.
\end{abstract}

Kata kunci: Hasil bon; auto regresif lat tertabur (ARDL); model dana boleh pinjam

\section{ABSTRACT}

The movement of government bond yields plays an important role in the economic governance of a country, especially to the government, investors and fund managers. A relatively high government bond yield rate will increase the cost of paying interest rates by the government, and if this situation is prolonged it will affect the future financial position of the government. Hence, this study aims to analyze the factors affecting the movement of the government bonds yield based on the three terms structure of interest rates namely short term, medium term and long-term bonds. The determinants of bond yield are analyzed using an auto regressive distributed lag (ARDL) model. The findings show that there is a co-integration or long-term relationships between fiscal deficit variables, government debt, foreign exchange rates, and economic growth on all structures of bond yield. In addition, in the long run, fiscal deficits, government debt and exchange rates have significant influenced on government bond yields. The findings of this study suggest that fiscal policy makers need to be more careful in governing budget deficits and national debt, as well as the role of Bank Negara Malaysia in controlling the stability of foreign exchange rates to ensure the stability of government bonds interest rates for national interest.

Keyword: Bond yield; autoregressive distributed lag (ARDL); loanable funds model

\section{PENGENALAN}

Pasaran bon kerajaan memainkan peranan penting kepada pembangunan ekonomi di sesebuah negara khususnya dalam mendapatkan sumber pembiayaan bagi menampung defisit belanjawan. Bon terbitan kerajaan kebiasaannya disandarkan kepada kepercayaan dan kredibiliti sesebuah kerajaan yang mempunyai perkaitan rapat dengan takbir urus sesebuah negara. Krisis kewangan yang melanda di Eropah pada 2007/2008 adalah contoh terbaik yang menunjukkan kepentingan takbir urus yang baik dalam pasaran bon kerajaan untuk menstabilkan ekonomi negara. Krisis kewangan Eropah tersebut telah membawa kepada peningkatan kadar hasil bon kerajaan di Greece, Sepanyol, Portugal dan Itali yang telah mencetuskan krisis hutang, meningkatkan defisit fiskal di negara-negara berkenaan dan menjejaskan keupayaan kerajaan untuk membuat pinjaman baharu.

Dalam pasaran bon, pergerakan kadar hasil bon memberikan maklumat penting kepada peserta pasaran khususnya pihak pelabur, dan pengurus dana (domestik dan antarabangsa) yang membeli bon terbitan kerajaan. Ini kerana sebarang perubahan terhadap kadar hasil bon memberikan implikasi kepada takbir urus portfolio pelaburan. Sekiranya berlaku peningkatan kadar hasil bon, keadaan ini mencerminkan tahap risiko pemegangan bon yang semakin tinggi pada masa hadapan. Sebaliknya, kepada pihak kerajaan yang menerbitkan bon, peningkatan kadar hasil bon akan meningkatkan pembayaran bunga kepada pemegang bon, yang mana situasi ini memberikan kesan kepada kedudukan kewangan kerajaan 